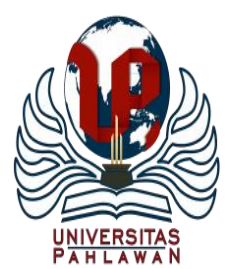

Edukatif : Jurnal Ilmu Pendidikan Volume 3 Nomor 2 Tahun 2021 Halm 611 - 618

EDUKATIF: JURNAL ILMU PENDIDIKAN

Research \& Learning in Education

https://edukatif.org/index.php/edukatif/index

\title{
Reaktualisasi Nilai Pancasila dan Implementasinya sebagai Upaya Pembangunan Karakter Bangsa
}

\author{
Siti Utami Mutmainah ${ }^{1 凶}$, Dinie Anggraeni Dewi ${ }^{2}$ \\ Universitas Pendidikan Indonesia, Indonesia ${ }^{1,2}$ \\ E-mail: sitiutamimth@upi.edu ${ }^{1}$, dinieanggraenidewi@upi.edu ${ }^{2}$
}

\begin{abstract}
Abstrak
Penelitian ini dilakukan berdasarkan permasalahan pada karakter anak bangsa yang dilihat semakin jauh dari nilai-nilai Pancasila yang salah satunya disebabkan karena perkembangan zaman. Penelitian ini bertujuan untuk mengaktualisasikan kembali nilai-nilai Pancasila yang selama ini dirasa mengalami berbagai tantangan yang menjadikan pancasila bukan lagi dengan makna yang sebenarnya. Penelitian ini dilakukan melalui metode kualitatif dengan teknis analisis untuk mereaktualisasi nilai Pancasila dan implementasinya sebagai upaya pembangunan karakter bangsa yang mana dasar pembahasannya di peroleh dari hasil studi kepustakaan berbagai sumber seperti buku, artikel jurnal, dan laporan hasil penelitian sebelumnya yang kemudian disajikan dalam bentuk deskriptif. Sebagaimana yang telah kita ketahui bahwa Pancasila merupakan ideologi, dasar negara dan pandangan hidup bangsa Indonesia yang seharusnya menjadi pedoman dan tolak ukur bangsa Indonesia dalam menjalankan kehidupan. Tetapi, di era globalisasi sekarang ini nilai-nilai pancasila terancam punah, sehingga karakter bangsa Indonesia yang seharusnya sesuai dengan pancasila kini mengalami perubahan. Oleh karenanya, dengan mengaktualisasi kembali nilai-nilai pancasila diharapkan bisa meningkatkan karakter bangsa Indonesia sesuai dengan makna Pancasila yang sebenarnya. Dengan demikian, dapat disimpulkan bahwa dengan pengaktualisasian kembali nilai Pancasila dapat membangun karakter anak bangsa yang berkualitas.
\end{abstract}

Kata Kunci: Pancasila, Reaktualisasi Nilai Pancasila, Pembangunan Karakter Bangsa.

\begin{abstract}
This research was conducted based on problems in the character of the nation's children who are seen as further away from the values of Pancasila, one of which is due to the times. This study aims to re-actualize the values of Pancasila which have been experiencing various challenges so that Pancasila is no longer with its true meaning. This research was conducted through qualitative methods with technical analysis to actualize the value of Pancasila and its implementation as an effort to build the nation's character where the basis for the discussion was obtained from the results of literature studies of various sources such as books, journal articles, and reports of previous research results which were then presented in descriptive form. As we already know, Pancasila is an ideology, the basis of the state and the way of life of the Indonesian nation which should be the guidelines and benchmarks for the Indonesian nation in running life. However, in the current era of globalization, the values of Pancasila are threatened with extinction, so that the character of the Indonesian nation which should be in accordance with Pancasila is now undergoing changes. Therefore, by re-actualizing the values of Pancasila, it is hoped that it can improve the character of the Indonesian nation in accordance with the true meaning of Pancasila. Thus, it can be concluded that by re-actualizing the values of Pancasila, it can build quality character of the nation's children.
\end{abstract}

Keywords: Pancasila, Reactualization of Pancasila Values, Development of National Character.

Copyright (c) 2021 Siti Utami Mutmainah, Dinie Anggraeni Dewi

$\triangle$ Corresponding author

Email : sitiutamimth@upi.edu

DOI : https://doi.org/10.31004/edukatif.v3i2.396

ISSN 2656-8063 (Media Cetak)

ISSN 2656-8071 (Media Online) 
612 Reaktualisasi Nilai Pancasila dan Implementasinya Sebagai Upaya Pembangunan Karakter Bangsa - Siti Utami Mutmainah, Dinie Anggraeni Dewi

DOI: https://doi.org/10.31004/edukatif.v3i2.396

\section{PENDAHULUAN}

Seiring dengan kemajuan zaman dan kecanggihan teknologi, karakter anak bangsa perlu menjadi perhatian. Karena, hal tersebut akan mempengaruhi segala aspek, mulai dari tutur kata, prilaku, hingga cara berpakaian yang dapat mengancam kualitas moral anak bangsa. Dari pemaparan tersebut, maka kita perlu menyiapkan diri sebagai warga negara yang menjadikan dasar negara Pancasila sebagai pandangan hidup. Sebagaimana yang telah kita ketahui bersama, bahwasannya Pancasila merupakan ideologi dasar bagi Indonesia yang memiliki tujuan untuk menjadikan warga negaranya yang baik. Hal itulah yang menguatkan betapa pentingnya Pancasila dijadikan sebagai pedoman warga negara Indonesia dalam hidupnya, guna mencetak warga negara yang berprilaku baik sesuai dengan Pancasila, karena dalam Pancasila itu sendiri jelas terkandung nilai-nilai yang mengajarkan kepada warga negara Indonesia bagaimana seharusnya berfikir dan bertindak.

Ketika Indonesia terbentuk, para founding fathers sepakat untuk menjadikan Pancasila sebagai dasar negara. Dengan perjalanan panjangnya Pancasila sebagai ideologi negara, pastinya sering dihadapkan berbagai tantangan yang menyebabkan Pancasila itu mengalami penambahan, pengurangan bahkan penyimpangan dari makna yang seharusnya. Permasalahannya muncul mulai dari pemerintahan orde lama yaitu sistem demokrasi liberal, lalu pemerintahan orde baru yang dianggap liberalisme kapitalistik, hingga sekarang di era reformasi ini pengamalan Pancasila dirasa masih kurang karena adanya kemerosotan moral bangsa. Riset menunjukan bahwa salah satu kemerosotan moral sekarang ini dikarenakan pengaruh negatif dari pesatnya globalisasi dan teknologi, banyak sekali pengaruh negatif terhadap bangsa kita, salah satunya yaitu lunturnya nilai-nilai luhur Pancasila (Wahyudi, 2016). Lantas, bagaimana cara untuk membangkitkan kembali karakter atau moral bangsa? Salah satunya adalah dengan mengaktualisasi kembali Pancasila yang menjadi pedoman hidup dan dasar negara Indonesia yang akan peneliti bahas.

Dari pengaruh globalisasi yang tidak terkontrol itu menjadikan budaya luar masuk dengan bebas dan dengan mudah dicerna masyarakat kita tanpa peduli sesuaikah dengan Pancasila ditambah lagi dengan kurangnya pemahaman masyarakat terhadap Pancasila itu sendiri. Akankah Pancasila kita kembali? melihat situasi dan kondisi Indonesia saat ini, ancaman terhadap Pancasila adalah pengaruh negatif globalisasi. Dengan begitu mudahnya pengaruh budaya luar masuk ke Indonesia, maka dengan tidak disadari akan berdampak pada karakter bangsa, karena jika diperhatikan masyarakat sekarang cenderung lebih menyukai budaya luar dibanding budaya leluhur bangsa sendiri. Permasalahan tersebut sangat dikhawatirkan karena menjadikan masyarakat Indonesia akan lupa terhadap jati diri bangsanya sendiri.

Pengaruh negatif globalisasi terhadap Pancasila di atas teridentifikasi dalam ketetapan MPR No/ V/ MPR/ 2000 tentang Pemantapan Persatuan dan Kesatuan dan Kondisi Bangsa Indonesia saat ini (Damanhuri et al., 2016). Ketetapan tersebut menyebutkan bahwa nilai-nilai agama dan budaya bangsa tidak lagi dijadikan sumber etika dalam berbangsa dan bernegara oleh sebagian masyarakat, yang pada akhirnya akan melahirkan krisis akhlak dan moral karena kurangnya pemahaman dan penghayatan terhadap nilai-nilai yang terkandung pada setiap sila Pancasila. Sebagaimana yang kita tahu bahwa akhlak atau moral merupakan suatu hal yang perlu diperhatikan, karena percuma saja berilmu jika tidak berakhlak contohnya seperti para koruptor yang memang pintar tapi salah menggunakan kepintarannya karena tidak dilandasi dengan akhlak yang baik. Maka, dari sini penelitian ini dilakukan dengan mengaktualisasi kembali nilai Pancasila dan mengimplementasikannya di kehidupan sehari-hari guna mencetak manusia yang berakhlak dan berkarakter baik. 
613 Reaktualisasi Nilai Pancasila dan Implementasinya Sebagai Upaya Pembangunan Karakter Bangsa - Siti Utami Mutmainah, Dinie Anggraeni Dewi

DOI: https://doi.org/10.31004/edukatif.v3i2.396

\section{METODE PENELITIAN}

Metodologi penelitian yang digunakan dalam penulisan ini adalah metode kualitatif di mana peneliti mencari dan memahami makna terkait nilai-nilai Pancasila juga pendidikan karakter dan menulisakannya secara deskriptif, yaitu suatu motode dalam penelitian suatu kelompok manusia, objek atau kondisi, sistem pemikiran ataupun kelas peristiwa yang terjadi sekarang (Subana, 2005). Selanjutnya, dalam pengumpulan datanya peneliti menyusun artikel ini menggunakan pendekatan secara study literature, artinya peneliti menggunakan literatur kepustakaan dengan menganalisis dari sumber data yang relevan berupa buku, artikel jurnal, dan laporan hasil penelitian sebelumnya yang berhubungan dengan reaktualisasi nilai Pancasila dan implementasinya sebagai upaya pendidikan karakter bangsa.

\section{HASIL DAN PEMBAHASAN}

\section{Reaktualisasi Nilai - Nilai Pancasila}

Sebelum penulis membahas mengenai reaktualisasi nilai-nilai Pancasila, alangkah baiknya penulis menerangkan terlebih dahulu Pancasila itu sendiri. Pancasila merupakan perjalanan panjang bangsa Indonesia, dimana dalam perjalanan panjang itu terdapat berbagai macam tantangan yang menjadikan Pancasila bukan lagi sebagai dasar dan ideologi negara. Pancasila merupakan falsafah bangsa Indonesia yang mengalami banyak tantangan salah satunya menggantikan keberadaan Pacasila dari hati sanubari bangsa Indonesia (Yudhanti, 2016). Selanjutnya, Pancasila juga merupakan pandangan hidup bangsa Indonesia yang berKetuhanan Maha Esa juga menjunjung tinggi kemanusiaan, persatuan, kesatuan, dan keadilan bagi seluruh rakyatnya.

Setelah mengetahui apa itu Pancasila, penting bagi kita untuk mereaktualisasi nilai-nilai Pancasila guna menumbuhkan kembali jiwa Pancasila di hati sanubari di tengah arus globalisasi saat ini. Reaktualisasi nilainilai Pancasila adalah cara bagaimana yang harus kita lakukan untuk kita bisa mengamalkan kembali nilainilai Pancasila yang seharusnya (Wahyudi, 2016). Karena, seperti yang telah kita ketahui, bahwa sekarang ini Indonesia berada di tengah-tengah perkembangan dunia yang mana di era ini banyak teknologi yang super canggih. Maka dari itu, memudahkan bangsa Indonesia untuk menerima hal baru dari luar, yang menyebabkan Pancasila terancam. Dengan demikian disinilah perlunya reaktualisasi nilai-nilai Pancasila.

Aktualisasi Pancasila itu harus dimulai dari semua aspek lingkungan, baik itu dari lingkungan keluarga, sekolah maupun masyarakat (Pahlevi, 2014). Dari semua aspek lingkungan tersebut harus dikuatkan dengan pendidikan nilai-nilai pancasila. Karena, apabila bangsa Indonesia tidak mengaktualisasikan nilai-nilai Pancasil, maka Indonesia akan terpengaruh dengan ideologi lain.

Selanjutnya, alasan normatif dan teoritik mengapa perlu reaktualisasi Pancasila adalah Pancasila sebagai ideologi dan norma dasar (fundamental norm) dalam kehidupan berbangsa dan bernegara (Widisuseno, 2014). Terakhir, alasan praktisnya adalah ancaman ideologis dan demografis sebagaimana yang telah dijelaskan sebelumnya.

\section{Hakikat Pembangunan Karakter Bangsa Indonesia}

Pembangunan karakter bangsa merupakan suatu hal yang perlu ditindak lanjuti. Mengapa demikian? karena, karakter itu berhubungan dengan proses pembinaan dan perbaikan perilaku juga nilai luhur yang pastinya harus di jiwai sesuai dengan nilai-nilai Pancasila dan UUD 1945 (Harmawati \& Abdulkarim, 2016). Pembangunan karakter juga merupakan salah satu upaya untuk mengamalkan amanat dari Pancasila dan pembukaan UUD 1945, mengingat zaman sekarang banyak permasalahan yang muncul, seperti kemerosotan moral, disintegrasi bangsa dan lunturnya niali-nilai budaya (Wahyudi, 2016). 
Untuk mengatasi permasalahan tersebut, pemerintah menjadikan pembangunan karakter sebagai upaya pembangunan nasional yang menjadikan pendidikan karakter sebagai landasan untuk merealisasikan dari visi pembangunan nasional tersebut. Pembangunan karakter bangsa ini memiliki urgensi yang sangat luas dan bersifat multidimensional (Pacinongi \& Asrifan, 2020). Sangat luas disini, maksudnya karena berkaitan dengan pengembangan potensi bangsa, sedangkan bersifat multidimensional di sini karena mencakup dimensi kebangsaan yang hingga saat ini masih dalam proses.

\section{Dasar Filosofi Implementasi Pendidikan Karakter}

Setiap bangsa pasti memiliki karakter sebagai identitas dan jati diri bangsa itu sedniri. Karakter merupakan nilai dasar yang menjadi tolak ukur saat interaksi antar manusia berlangsung, karakter juga digunakan sebagai cara berfikir dan berprilaku tiap individu (Zaman, 2019). Selanjutnya, pendidikan karakter sendiri merupakan merupakan upaya untuk membentuk karakter yang tentunya dipengaruhi oleh lingkungan. Pendidikan karakter juga dijadikan sebagai pondasi untuk membangun pribadi individu yang salah satunya bisa terbentuk karena pengaruh genetik maupun lingkungan sekitarnya (Samani \& Hariyanto., 2013). Melalui pendidikan karakter ini diharapkan dengan menggunakan pengetahuannya mampu untuk meningkatkan akhlak dalam kehidupan.

Sebelum pendidikan karakter diimplementasikan, perlu diketahui terlebih dahulu hal penting apa yang harus disepakati secara rasional tentang dasar filosofi bagi pengimplemntasian pendidikan karakter di Indonesia (Rosad, 2019). Nah, jika melihat kesepakatan para founding fathers kita saat mendirikan negara Indonesia ini dahulu, mereka bersepakat untuk menjadikan Pancasila sebagai filosofinya. Jadi, dalam hal membentuk karakter bangsa Indonesia, kita seutuhnya bertuju ke nilai-nilai Pancasila.

Dalam pengimplemtasian pendidikan karakter ini, tentunya tidak dapat dilakukan tanpa pembiasaan dari penanaman nilai- nilai Pancasila itu sendiri, yang mana karakter itu berasal dari nilai tentang sesuatu sebagaimana penulis jelaskan sebelumnya. Nah, suatu nilai yang diwujudkan dalam bentuk prilaku itulah yang disebut karakter. Jadi, suatu karakter itu melekat dengan nilai dan prilaku tersebut.

\section{Kedudukan Pancasila dan Aktualisasi Nilai-Nilainya dalam Berbangsa dan Bernegara}

Berbicara mengenai Pancasila, pastinya suatu hal yang tidak asing lagi bagi kita. Karena, selama kita menempuh pendidikan di semua jenjang pasti didalamnya terkandung materi-materi atau nilai-nilai Pancasila. Secara bahasa, Pancasila berasal dari Sanskerta yang terdiri atas dua kata yaitu "panca" dan "sila". Panca yang berarti lima dan sila yang berarti dasar atau prinsip atau asas (Aziz \& Rana, 2019). Jadi, Pancasila merupakan seperangkat lima aturan tentang prinsip, petunjuk dan perilaku masyarakat bangsa indonesia, yang mana kelima sila tersebut sangat berperan untuk dijadikan pandangan hidup, keyakinan, dan cita-cita bangsa indonesia.

Bangsa Indonesia sebenarnya telah mengenal nilai-nilai Pancasila jauh sebelum Indonesia merdeka. Buktinya, dari zaman dahulu juga bangsa Indonesia telah percaya akan animisme dan dinamisme. Kepercayaan itu jika merujuk ke Pancasila merupakan pengamalan dari sila pertama. Bukti lain bahwa Indonesia telah menerapkan nilai-nilai Pancasila adalah adanya bangsa Indonesia yang bersatu dan gotong royong dalam melawan penjajah. Dari sini dapat ditarik kesimpulan bahwasannnya Pancasila itu lahir dari bangsa Indonesia sendiri. Seperti perkataan Ir. Soekarno yang menyatakan bahwa beliau bukanlah pencipta Pancasila apalagi membuatnya, tapi beliau hanya mempopulerkannya. Karena, pada hakikatnya Pancasila itu tercipta dan sudah ada dari dalam diri bangsa Indonesia sejak lalu.

Sejarah telah mencatat bahwa Pancasila merupakan hasil kesepakatan para founding fathers yang merupakan jiwa seluruh rakyat Indonesia. Pancasila adalah sang pemberi kekuatan hidup dan membimbing bangsa Indonesia ke arah yang lebih baik lagi. Untuk kelestarian Pancasila sendiri perlu pelestarian dan pengamalan nilai-nilai luhirnya oleh setiap warga negara. Segala aturan kehidupan negara ini haruslah 
mengacu pada nilai-nilai dasar dari Pancasila (Pahlevi, 2014), yang mana nilai-nilai tersebut diantaranya, yang pertama Nilai Ketuhanan. Sila yang pertama Pancasila adalah Ketuhanan yang Maha Esa. Dalam sila ini mengandung pengakuan dan kepercayaan kepada Tuhan Yang Maha Esa, yang menurut agamanya masingmasing. Kedua, Nilai Kemanusiaan. Sila kedua Pancasila adalah Kemanusiaan yang Adil dan Beradab. Dalam sila ini tekandung kesesuaian antar hakikat manusia, di mana nilai dalam sila ini mengakui bahwasannya manusia itu mempunyai kedudukan, hak dan kewajiban yang sama dan sederajat.

Selanjutnya, ketiga Nilai Persatuan. Sila ketiga Pancasila adalah Persatuan Indonesia. Nilai dalam sila ketiga ini adalah bahwa kita harus mendahulukan kepentingan bangsa di banding kepentingan individu atau kelompok serta berpegang teguh pada Bhinneka Tunggal Ika. Keempat, Nilai Kerakyatan. Sila keempat Pancasila adalah Kerakyatan yang Dipimpin oleh Hikmat Kebijaksaan dalam Permusyawaratan Perwakilan. Dalam sila ini perlu di garis bawahi kata kerakyatannya, kata kerakyatan disini merupakan kunci yang rakyat mempunyai kedudukan tertinggi dalam penyelenggaraan sistem negara Indonesia. Terakhir, kelima Nilai Keadilan. Sila kelima Pancasila adalah Keadilan bagi Seluruh Rakyat Indonesia. Nilai dari sila kelima ini adalah adil terhadap sesuatu baik pada diri sendiri maupun orang lain. Nilai ini juga termasuk salah satu tujuan negara Indonesia sendiri, yaitu mewujudkan tatanan masyarakat yang adil dan makmur.

Seperti yang telah penulis jelaskan tadi, bahwa aktualisasi nilai Pancasila ini perlu di implementasikan dalam kehidupan berbangsa dan bernegara agar mencetak generasi yang berkarakter. Aktualisasi nilai Pancasila dalam praktek di kehidupan itu mengarahkan kepada 3 nilai yang terkandung dalam Pancasila (Alaby, 2019). Tiga nilai tersebut diantaranya, pertama Nilai Dasar. Nilai dasar merupakan suatu nilai yang bersifat amat abstrak, tetap dan permanen. Nilai dasar ini merupakan hakikat kelima Pancasila itu sendiri yang mengandung lima dasar sebagaimana yang tadi penulis jelaskan, lima nilai dasar pancasila itu diantaranya dalam sila pertama ada nilai ketuhanan, sila kedua nilai kemanusiaan, sila ketiga nilai persatuan, sila keempat kerakyatan dan dan sila kelima mengandung nilai keadilan. Kedua, Nilai Instrumental. Nilai instrumental Pancasila ini merupakan penjabaran dari nilai-nilai dasar tadi. Perwujudan dari nilai instrumental ini pada umumnya dituangkan dalam bentuk ketentuan konstitusional mulai dari Undang-Undang Dasar sampai peraturan daerah. Terakhir, ketiga Nilai Praksis. Pada dasarnya, nilai praksis inilah yang merupakan realisasi dari nilai-nilai instrumental yang merupakan perwujudan dari peraturan yang termuat dalam peraturan perundang-undangan. Bisa dikatakan nilai praksis ini adalah sikap sehari-hari kita yang tentunnya harus sesuai dengan ketentuan konstitusional. Nilai praksis Pancasila ini akan selalu berubah seiring dengan perkembangan zaman.

\section{Nilai Pendidikan Karakter Bangsa Indonesia Berdasarkan Pancasila}

Arah pikir pengembangan karakter Indonesia ini menunjuk pendidikan sebagai salah satu upaya dasar dari pembangunan karakter bangsa (Kemdiknas, 2011). Dimana pelaksaan hal tersebut harus dilakukan dengan beberapa strategi diantaranya penyadaran, pembudayaan, dan pemberdayaan juga kerja sama. Pembangunan karakter ini dilakukan dengan pendekatan secara sistematis yang melibatkan keluarga tentunya, sekolah, juga masyarakat dan media massa. Dalam melaksanakan pembentukan karakter, diperlukan pula tekad yang sungguh-sungguh sehingga bisa menjadikan anak bangsa berkarakter baik yang tentu saja ini semua dilakukan berdasarkan kepada Pancasila.

Selama ini, nilai prinsip Pancasila sendiri sebenarnya telah diwariskan juga telah menjadi kesepakatan seluruh rakyat Indonesia. Prinsip Pancasila yang tercantum dalam UUD 1945 itu diantaranya mengenai sistem NKRI, HAM, dan Bhineka Tunggal Ika (Suhady \& Sinaga, 2006).

Melihat nilai prinsip Pancasila tersebut, maka pendidikan karakter yang dikembangkan di Indonesia ini mengarah kepada pembentukan bangsa yang berkarakter baik, berjiwa patriotik juga tangguh, kompetitif dan berorientasi ilmu pengetahuan dan teknologi, bermoral juga bertoleran, bergotong royong dan menghargai, yang semuanya itu dijiwai oleh iman takwa kepada Tuhan yang Maha Esa (Rachmah, 2016). 
616 Reaktualisasi Nilai Pancasila dan Implementasinya Sebagai Upaya Pembangunan Karakter Bangsa - Siti Utami Mutmainah, Dinie Anggraeni Dewi

DOI: https://doi.org/10.31004/edukatif.v3i2.396

\section{Reaktualisasi Nilai Pancasila dan Implementasinya Sebagai Upaya Pembangunan Karakter Bangsa}

Seperti yang telah kita ketahui dan alami sekarang, Indonesia kita ini sedang berada di tengah-tengah fase perkembangan dunia yang serba modern. Semua teknlogi canggih ada di zaman globalisasi ini, yang meliputi semua aspek kehidupan manusia, mulai dari ekonomi hingga sosial. Dari permasalahan demikian tentu saja mengancam Pancasila sebagai dasar negara sekaligus ideologi dan pandangan hidup kita. Sejalan dengan pemikiran (Nurgiansah, 2021) yang menyatakan bahwa Pancasila kita sekarang ini sudah hampir tidak diamalkan lagi dalam kehidupan dan tidak banyak orang yang sepenuhnya dapat jujur yang disebabkan karena faktor perkembangan zaman.

Dilihat secara politik, Pancasila itu perlu diaktualisasi kembali (reaktualisasi) melihat secara yuridis Pancasila merupakan dasar dari Negara Kesatuan Republik Indonesia sebagiamana yang telah dirumuskan dalam pembukaan UUD 1945 (Wahyudi, 2016). Dari perjalanan panjangnya yang selalu ditempa berbagai permasalahan, sehingga perlu pengaktualisasian kembali.

Aspek pendidikan memandang bahwa Pancasila itu perlu diaktualisasikan kembali (reaktualisasi), karena Pancasila sekarang ini kurang dipahami oleh masyrakat, sehingga dalam pengamalannya pun sulit dilakukan. Oleh karena itu, Pancasila perlu dipahami kembali agar dapat diamalkan kembali masyarakat Indonesia. Dengan demikian, kita generasi muda yang sedang menempuh pendidikan sudah seharusnya belajar dengan baik agar mampu memahami nilai-nilai Pancasila dan dapat mengamalkannya.

Begitu pula pada aspek kesejahteraan rakyat, yang memandang perlunya Pancasila diaktualisasikan kembali (reaktualisasi), karena Pancasila merupakan kunci dari sejahteranya rakyat Indonesia. Melihat kondisi sekarang, bangsa Indonesia sedang mengalami kemerosotan moral, krisis kepercayaan, gangguan toleransi dan masih banyak lagi. Oleh karena itu, dengan mereaktualisasi nilai-nilai Pancasila ini diharapkan bisa mengurangi permasalahan tersebut.

Selanjutnya, untuk mengaktualisasikan Pancasila, maka kiranya kita perlu melihat terlebih dahulu situasi dan kondisi bangsa Indonesia saat ini, yang mana sekarang ini kita sedang berada di perkembangan dunia modern. Oleh karena itu, diperlukanlah metode atau pendekatan yang tepat agar bisa terrealisasi. Sebab bangsa Indonesia memiliki dasar negara yang istimewa, maka pendekatan yang tepat yaitu menggunakan Pendekatan Pancasilais. Lantas, apa itu pendekatan Pancasilais?

Pendekatan Pancasilais merupakan cara berfikir dan berperilaku bangsa Indonesia dalam kehidupannya sehari-hari, baik itu di lingkungan keluarga maupun masyarakat (Wahyudi, 2016). Pendekatan Pancasilais ini akan selalu mempertimbangkan apakah prilaku dan cara berfikir kita ini sesuaikah dengan pengamalan silasila Pancasila atau tidak, secara tidak langsung pendekatan ini mengajarkan untuk kita konsisten dalam berprilaku dan berfikir sesuai dengan sila-sila Pancasila.

Adapun sasaran dari aktualisasi nilai-nilai Pancasila ini merupakan upaya untuk pembangunan karakter bangsa. Selanjutnya karena berkaitan dengan pendidikan karakter, maka diperlukan pula keteladanan. Hal ini pun sudah menjadi perhatian pemerintah, hingga saat ini pemerintah sangat menekankan pentingnya pendidikan karakter yang sesuai dengan Pancasila salah satu upayanya adalah dengan menerapkan di ranah pendidikan dengan harapan dapat membangun karakter generasi muda yang sesuai dengan Pancasila. Di sisi lain, pendidikan karakter juga merupakan modal dasar untuk melaksanakan pembangunan bidang lain (Zaman, 2019), misalnya saja aspek politik Indonesia akan berhasil jika para pejabatnya memiliki karakter atau akhlak yang baik, begitu juga dengan aspek kesejahteraan rakyat akan tercipta jika semua rakyat berkarakter baik. 
617 Reaktualisasi Nilai Pancasila dan Implementasinya Sebagai Upaya Pembangunan Karakter Bangsa - Siti Utami Mutmainah, Dinie Anggraeni Dewi

DOI: https://doi.org/10.31004/edukatif.v3i2.396

\section{KESIMPULAN}

Indonesia saat ini sedang berada di tengah-tengah dunia modern. Dengan pesatnya globalisasi dan teknologi ini akan menjadi ancaman bagi Pancasila sebagai dasar negara, ideologi dan pandangan hidup bangsa Indonesia. Dari permasalahn tersebut, tentunya perlu pengaktualisasian kembali (reaktualisasi) mengenai nilai-nilai Pancasila dan implementasinya adalah dengan pembangunan karakter. Reaktualisasi nilai-nilai Pancasila merupakan cara bagaimana yang harus kita lakukan untuk kita bisa mengamalkan kembali nilai-nilai Pancasila yang seharusnya. Reaktualisasi tersebut merupakan salah satu upaya pembangunan karakter bangsa. Pembangunan karakter bangsa merupakan suatu hal yang perlu ditindak lanjuti. Mengapa demikian? karena, karakter itu berhubungan dengan proses pembinaan dan perbaikan perilaku juga nilai luhur yang pastinya harus dijiwai dan sesuai dengan nilai-nilai Pancasila dan UUD 1945. Dengan adanya artikel ini, diharapkan peran anak bangsa sebagai generasi penerus meningkatkan lagi dalam menjaga dan mengamalkan nilai-nilai pancasila, agar menjadi pribadi yang berkualitas juga memiliki karakter yang baik sesuai dengan Pancasila sebagai falsafah bangsa Indonesia.

\section{UCAPAN TERIMA KASIH}

Dengan selesainya tulisan ini, penulis mengucapkan terima kasih kepada dosen pengampu mata kuliah Pendidikan Pancasila Universitas Pendidikan Indonesia yang telah membantu dalam penyelesaian penelitian. Selanjutnya, tidak lupa penulis mengucapkan terima kasih kepada ketua dewan redaksi Edukatif Jurnal Ilmu Pendidikan yang telah memproses artikel hingga layak dimuat di jurnal pada edisi sekarang ini.

\section{DAFTAR PUSTAKA}

Alaby, M. A. (2019). Membumikan Nilai Pancasila pada Generasi Bangsa. Gema Wiralodra, 10(2), 179-190.

Aziz, A., \& Rana, M. (2019). (2019). PANCASILA DAN KERAGAMAN KEHIDUPAN MASYARAKAT DI INDONESIA Implementasi Nilai-nilai Pancasila pada Kehidupan Masyarakat di Indonesia.

Damanhuri, D., Bahrudin, F. A., Legiani, W. H., \& Rahman, I. N. (2016). Implementasi Nilai-Nilai Pancasila Sebagai Upaya Pembangunan Karakter Bangsa. Untirta Civic Education Journal, 1(2).

Harmawati, Y., \& Abdulkarim, A. (2016). Nilai budaya tradisi Dieng Culture Festival sebagai kearifan Lokal untuk Membangun karakter bangsa. Journal of Urban Society's Arts, 3(2), 82-95.

Kemdiknas. (2011). Panduan Pelaksanaan Pendidikan Karakter.

Nurgiansah, T. H. (2021). Pendidikan Pancasila sebagai upaya membentuk karakter jujur. Jurnal Pendidikan Kewarganegaraan Undiksha, 9(1), 33-41.

Pacinongi, A., \& Asrifan, A. (2020). Bimbingan Pengawas Berkelanjutan dalam Mewujudkan Pendidikan Karakter Bangsa dalam Kegiatan Belajar Mengajar Penjaskes. Celebes Education Review, 2(1), 1-7.

Pahlevi, F. (2014). Reaktualisasi Pancasila Sebagai Upaya Peningkatan Kualitas Pendidikan Moral Bangsa Indonesia. Al-Adabiya: Jurnal Kebudayaan Dan Keagamaan, 9, 21-44.

Rachmah, H. (2016). Nilai-nilai dalam pendidikan karakter bangsa yang berdasarkan Pancasila dan UUD 1945. E-Journal WIDYA Non-Eksakta, 1(1), 7-14.

Rosad, A. M. (2019). Implementasi Pendidikan Karakter Melalui Managemen Sekolah. Tarbawi: Jurnal Keilmuan Manajemen Pendidikan. 5(2), 173-190.

Samani, M., \& Hariyanto. (2013). Konsep dan Model Pendidikan Karakter. Remaja Rosdakarya.

Subana, M. (2005). Dasar-dasar Penelitian Ilmiah (P. Setia (ed.)). 
618 Reaktualisasi Nilai Pancasila dan Implementasinya Sebagai Upaya Pembangunan Karakter Bangsa - Siti Utami Mutmainah, Dinie Anggraeni Dewi

DOI: https://doi.org/10.31004/edukatif.v3i2.396

Suhady, I., \& Sinaga, A. M. (2006). awasan Kebangsaan dalam Kerangka Negara Kesatuan Republik Indonesia. Lembaga Administrasi Negara RI.

Wahyudi, W. (2016). Reaktualisasi Nilai-Nilai Pancasila Dalam Pembangunan Karakter Bangsa Indonesia. In Prosiding Seminar Nasional Inovasi Pendidikan.

Widisuseno, I. (2014). Azas Filosofis Pancasila Sebagai Ideologi Dan Dasar Negara. Humanika, 20(2), $62-66$.

Yudhanti, R. (2016). Pancasila dan Berbagai Permasalahan Aktual. Law Research Review Quarterly, 2, 599 610.

Zaman, B. (2019). Urgensi Pendidikan Karakter yang sesuai dengan Falsafah Bangsa Indonesia. Al Ghazali, $2(1), 16-31$. 